\title{
Pengontrolan Motor Stepper Menggunakan Driver DRV 8825 Berbasis Signal Square Wave dari Timer Mikrokontroler AVR
}

\author{
Arief Wisnu Wardhana*, Daru Tri Nugroho \\ Jurusan Teknik Elektro, Universitas Jenderal Soedirman \\ Corresponding authors e-mail : arief.wardhana@unsoed.ac.id
}

\begin{abstract}
Abstrak - Pada penelitian ini dirancang suatu rangkaian elektronik untuk mengendalikan motor stepper. Suatu IC kontroler digunakan sebagai piranti kontrolnya. Microcontroller Unit (MCU) digunakan untuk menghasilkan sinyal input. Rangkaian ini dicobakan pada dua jenis motor yaitu motor stepper Permanent Magnet dan motor stepper Hybrid. Berbagai mode stepping dilakukan pada penelitian ini, yaitu fullstepping, half-stepping dan microstepping. Beberapa profil pergerakan motor stepper yang biasa digunakan pada berbagai aplikasi juga dicobakan. Parameter pergerakan motor diamati, seperti besarnya kecepatan motor, seberapa halus suara motor yang dihasilkan, serta profil percepatannya. Hasil yang diperoleh adalah bahwa dengan menggunakan level microstepping yang lebih tinggi menyebabkan suara motor stepper menjadi lebih tidak terdengar. Hasil selanjutnya didapat bahwa dengan mengaplikasikan suatu profil percepatan di dalam program mikrokontroler, maka bisa ditargetkan suatu kecepatan motor stepper yang diperkirakan melebihi kecepatan start-on yang di support oleh motor stepper tersebut.
\end{abstract}

Kata Kunci : stepper motor, microcontroller unit, integrated circuit, microstepping, Permanent Magnet, Hybrid

\begin{abstract}
In this research, an electronic circuit system was designed for controlling stepper motors. A stepper motor driver IC was used to implement those control mechanism. A Microcontroller Unit (MCU) is used to generate the square-wave needed for input to motor driver. The circuit was used on two types of stepper motors, namely permanent magnet stepper motor and hybrid stepper motor. Several modes of controls are conducted here, which are full-stepping, half-stepping, and microstepping. Some useful motor movements which are often used in many applications were tried here. Observations were made on the speed of the motor for various input waveform frequencies, on the stepper motor sound for a range of microstepping level, and on the acceleration profile. Some significant results were obtained in that by using higher microstepping levels, a smoother stepper motor movement can be achieved. Another important result is that by applying an acceleration profile in the microcontroller program, we may target a speed which is well above the rated start-on speed of the stepper motor.
\end{abstract}

Keywords : stepper motor, microcontroller unit, stepper motor driver integrated circuit, full-stepping, half-stepping, microstepping

\section{Pendahuluan}

Pada bidang keteknikan, kita sering memanfaatkan berbagai tipe pergerakan dalam arah rotasional, bisa berbentuk satu putaran penuh, atau setengah putaran, seperempat dan seterusnya. Banyak instrumen, peralatan dan perangkat elektronik disekitar kita yang juga beroperasi dengan basis pergerakan rotasional ini. Beberapa aplikasi yang memanfaatkan tipe pergerakan ini diantaranya adalah automatic teller machines, money handling machines, video security cameras, printers, scanners, office automation machines, gaming machines, factory automation dan robotics.

Untuk membantu menggerakkan berbagai peralatan elektronik tersebut, tentunya dibutuhkan suatu perangkat alat atau instrumen bantu. Suatu alat yang bernama motor stepper bisa mengakomodasi kebutuhan ini.

Penelitian ini secara terperinci membahas gerakan rotasi pada piranti elektronik motor stepper. Beberapa tipe gerakan rotasi yang dianggap bisa dimanfaatkan oleh berbagai aplikasi dibahas pada penelitian ini.

Ada dua tujuan yang ingin didapatkan pada penelitian ini. Pertama adalah untuk membandingkan keluaran pergerakan motor 
stepper yang dihasilkan dari berbagai masukan pola stepping. Kedua, untuk merancang suatu profil pola kecepatan untuk memastikan bahwa motor stepper tidak akan pernah macet ketika sedang dipercepat atau diperlambat.

\section{Teori Motor Stepper}

Tidak seperti motor DC yang berputar secara kontinu setelah tegangan pengoperasiannya terlampaui, motor stepper berputar dengan langkah-langkah yang diskrit, dengan setiap langkahnya yang harus dipicu oleh rangkaian aplikasi nya. Dikarenakan setiap langkah pemutaran motor stepper berupa suatu sudut yang konstan, maka motor stepper adalah suatu piranti yang sangat presisi yang setiap gerakannya bisa diulang dengan mudah. Oleh karena itu, motor stepper sangat tepat untuk digunakan pada beberapa aplikasi seperti printer, plotter, disk drive.

Motor stepper bergerak dalam langkah-langkah yang sangat jelas terlihat selama pergerakan rotasinya. Setiap langkahnya didefinisikan dengan sebuah istilah yang disebut dengan step angle. Apabila diperhatikan pada contoh Gambar 1 di bawah ini, terlihat bahwa terdapat 4 langkah yang jelas agar rotor bisa menghasilkan satu rotasi lengkap sebesar $360^{\circ}$ (360 derajat). Gambar tersebut mendefinisikan sebuah step angle sebesar $90^{\circ}$ (90 derajat).

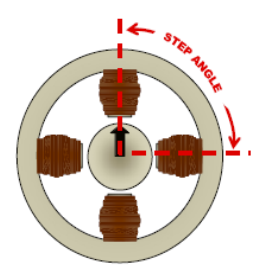

Start Position

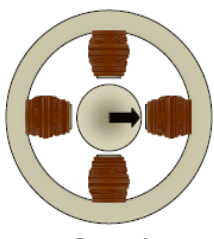

Step 1

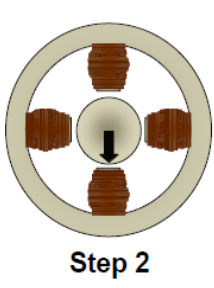

Step 2
Gambar 1. Stepper Motor [5].

Motor stepper merupakan suatu motor digital karena motor ini bergerak secara diskrit. Karakteristik ini yang menjadikan motor stepper sangat sesuai untuk sistem antarmuka dengan mikrokontroler.

\subsection{Stepper Motor Permanent Magnent}

Tipe dasar motor stepper terdiri atas dua jenis, yaitu tipe motor stepper Permanent Magnet (PM) dan tipe motor stepper Variable Reluctance (VR). Selain kedua tipe tersebut, terdapat juga tipe motor stepper Hybrid yang menggabungkan fitur yang terdapat pada Permanent Magnet dan Variable Reluctance.

Motor stepper PM pada dasarnya terdiri dari sebuah rotor yang terbuat dari magnet permanen dan dua pasangan kumparan stator (yang disebut fasa). Pada Gambar 2 ditunjukkan motor stepper $P M$ yang memiliki satu rotor dan sepasang kumparan stator.

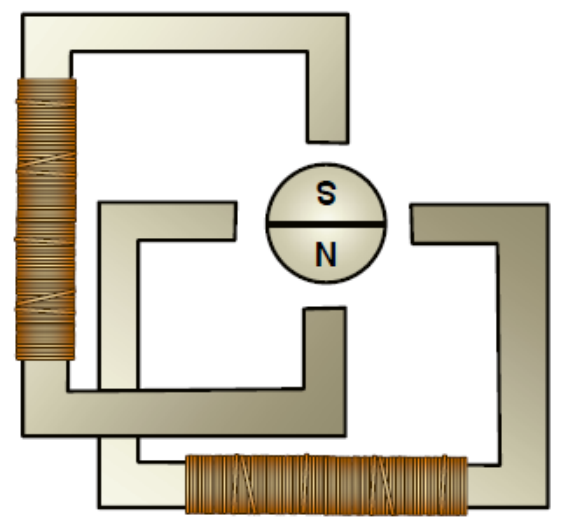

Gambar 2. Rotor dan sepasang kumparan stator pada sebuah stepper motor PM [5].

Jika suatu tegangan diaplikasikan ke salah satu kumparan, seperti terlihat pada Gambar 3, arus listrik akan mengalir melalui kumparan tersebut. Jika digunakan teori kaidah tangan kanan, posisi jari-jari yang melingkupi kumparan menunjukkan arah arus yang mengalir ke kumparan, sedangkan ibu jari menunjukkan arah magnetic flux. Hal ini menyebabkan setiap ujung stator menjadi termagnetisasi dengan kutub yang berlawanan. Magnetic flux tersebut akan mengalir dari kutub utara (north pole), dan kemudian berlanjut melewati magnetic rotor menuju ke kutub stator lainnya yaitu kutub selatan (south pole). Magnetic flux ini mempunyai kecenderungan untuk mengikuti lintasan dengan resistansi yang paling kecil atau kecenderungan untuk mengikuti lintasan dengan magnetic reluctance paling kecil.

Dengan demikian, rotor akan berputar untuk meminimalkan lintasan flux (meminimalkan reluctance). Jadi, jika suatu kumparan dialiri arus, kumparan tersebut akan menarik rotor, sehingga rotor akan menyesuaikan perputarannya sesuai dengan kumparan yang menariknya dan akhirnya rotor akan berhenti. 


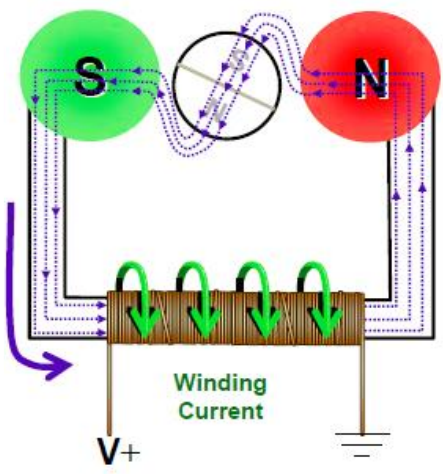

Gambar 3. Aplikasi tegangan ke sebuah kumparan [5].

Selanjutnya pada Gambar 4, apabila tegangan diberikan secara bergantian pada kumparan 1a, 2a, $1 \mathrm{~b}$, dan $2 \mathrm{~b}$ maka akan menyebabkan rotor berputar searah jarum jam dalam empat langkah yang berbeda dengan besarnya setiap langkah adalah $90^{\circ}$, sehingga terjadi satu putaran penuh.

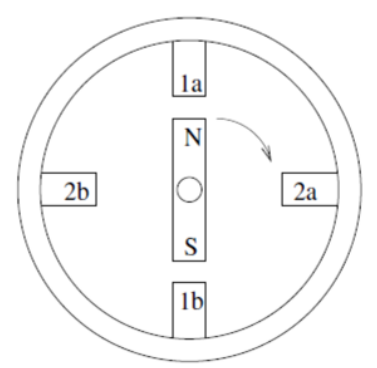

Gambar 4. Motor stepper permanent magnet [2].

Secara fisiknya, permanent magnet stepper motor dapat berupa jenis bipolar atau unipolar. Pada penelitian ini digunakan motor stepper bipolar, yaitu tipe NEMA, size 17, 1.8 2 -phase bipolar stepper motor 17HD40005-22B [7]. Sebagai pembanding, pada penelitian Ivan Virgala et. al. dilakukan percobaan dengan motor stepper bipolar SY28STH32-0674A [4].

Suatu stepper motor jenis bipolar mempunyai empat kabel yang masing-masing kabelnya dihubungkan dengan kumparan fasa. Hal ini ditunjukkan pada Gambar 5.

Polaritas dari sebuah fasa ditentukan oleh arah arus yang yang sedang melalui kumparannya. Untuk menjalankan motor stepper, dibutuhkan sebuah $H$-bridge, yaitu suatu perangkat hardware tambahan yang digunakan untuk menjalankan motor stepper. Perangkat tambahan ini juga disebut dengan stepper motor driver. Walaupun dibutuhkan perangkat tambahan ini, keuntungan yang diperoleh adalah motor stepper akan memiliki torque yang maksimum sehingga static position error menjadi menjadi lebih kecil.
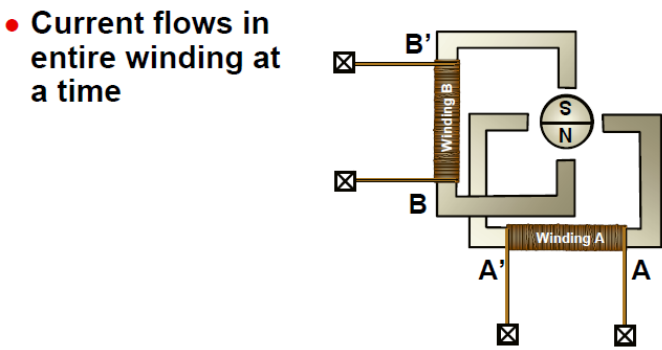

Gambar 5. Motor stepper bipolar [5].

\subsection{Memperbaiki Resolusi Rotor}

Ada beberapa metode agar resolusi rotasi rotor atau memperkecil besarnya step angle dari sebuah rotor permanent magnet dapat diperbaiki. Metode pertama adalah dengan menaikkan jumlah pasangan pole pada bagian rotor itu sendiri. Hal ini ditunjukkan pada Gambar 6 berikut:

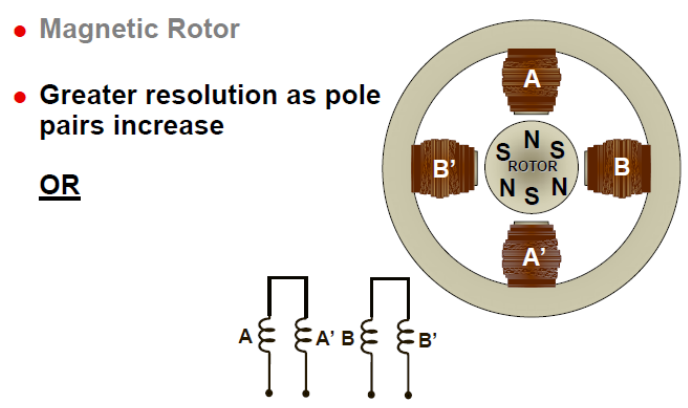

Gambar 6. Resolusi rotasi rotor menjadi lebih baik dengan menambah jumlah pasangan pole pada rotor [5].

Cara lain untuk memperbaiki resolusi rotasi rotor adalah dengan menambahkan banyak stator dan fasa. Metode ini ditunjukkan pada Gambar 7, dimana resolusi rotasi rotor diperbaiki secara hardware.

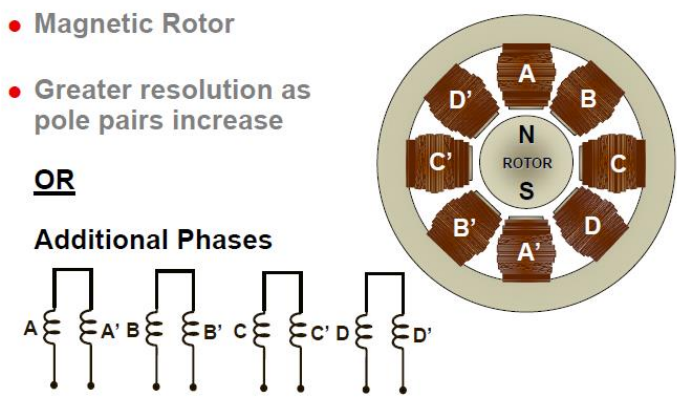

Gambar 7. Resolusi rotasi rotor menjadi lebih baik dengan penambahan stator dan fasa [5]. 
Metode selanjutnya untuk menaikkan resolusi rotasi rotor adalah dengan cara software, yaitu menggunakan berbagai teknik stepping [5]. Teknik inilah yang dilakukan pada penelitian ini.

Ada tiga pola stepping berbeda yang dapat digunakan untuk mempengaruhi posisi terindeks dari shaft (rotor). Pola-pola tersebut adalah fullstepping, half-stepping dan microstepping, seperti ditunjukkan pada Gambar 8. Pola stepping ini akan dijelaskan di sub bab selanjutnya.
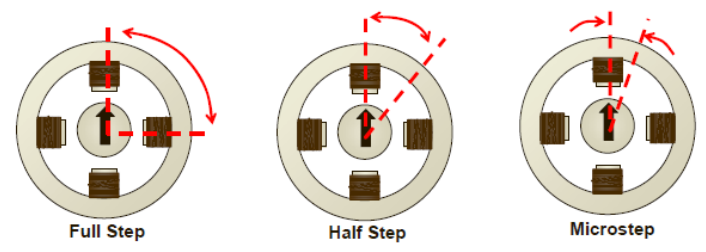

Gambar 8. Pola stepping [6].

\subsection{Speed Control}

Algoritma untuk Full-Stepping ditunjukkan oleh diagram pada Gambar 9 berikut ini. Diagram ini diperoleh dari penjelasan pada subbab 3 diatas. Pada Gambar 9 ini ditunjukkan bahwa setiap kumparan dapat diaktifkan secara secara bergantian.

\begin{tabular}{|c|c|c|c|c|}
\hline Step & $\mathbf{1}$ & $\mathbf{2}$ & $\mathbf{3}$ & $\mathbf{4}$ \\
\hline Winding A & A & 0 & A $^{\prime}$ & 0 \\
\hline Winding B & 0 & B & 0 & B' $^{\prime}$ \\
\hline
\end{tabular}

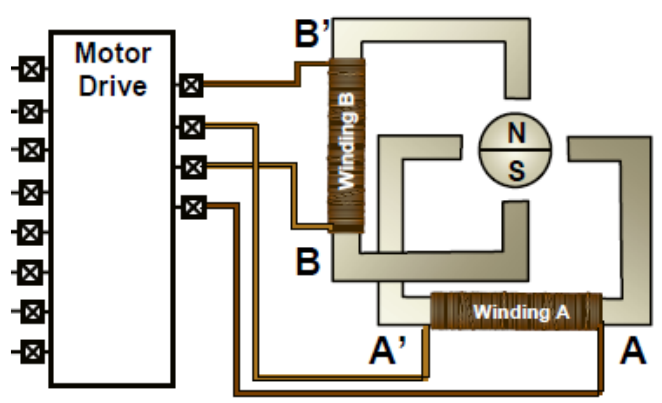

Gambar 9. Algoritma Full Stepping [6].

Pada motor stepper tipe Permanent Magnet, telah disebutkan bahwa mengaktifkan dua fasa secara bersamaan akan menaikkan torque, tetapi juga akan menaikkan konsumsi daya. Walaupun demikian, ada satu efek lain yang akhirnya membuat teknik ini menjadi berguna. Jika diperhatikan kembali Gambar 4, dengan mengaktifkan kumparan $1 \mathrm{a}+2 \mathrm{a}$ secara bersamaan, maka akan membawa rotor pada posisi pertengahan antara 1a dan 2a. Jadi, jika digunakan sekuensi pengaktifan $1 \mathrm{a}, 1 \mathrm{a}+2 \mathrm{a}, 2 \mathrm{a}, 2 \mathrm{a}+1 \mathrm{~b}, 1 \mathrm{~b}$, . . . , cara ini akan membagi dua step angle dari motor stepper tersebut, sehingga akan melipatgandakan jumlah step untuk setiap revolusinya. Teknik ini disebut dengan halfstepping.

Jadi, dengan penjelasan di atas dan dengan melihat diagram dan skema pada Gambar 10, algoritma untuk half-stepping adalah sebagai berikut [6] :

\begin{tabular}{|l|l|l|l|l|l|l|l|l|}
\hline Step & 1 & 2 & 3 & 4 & 5 & 6 & 7 & 8 \\
\hline Winding A & A & A & 0 & A'$^{\prime}$ & A'$^{\prime}$ & A'$^{\prime}$ & 0 & A \\
\hline Winding B & 0 & B & B & B & 0 & B'$^{\prime}$ & B' $^{\prime}$ & B' \\
\hline
\end{tabular}

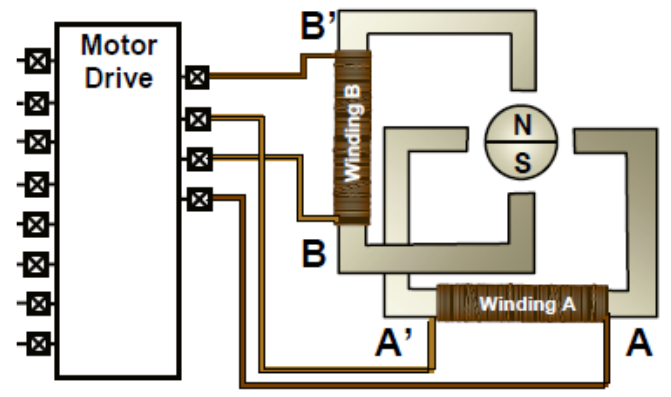

Gambar 10. Algoritma Half Stepping [6]

Selanjutnya, dengan merujuk kembali ke Gambar 10, apabila kedua kumparan tidak diaktifkan secara penuh, tetapi dimulai dengan kumparan A dan kemudian secara perlahan lahan menaikkan besarnya arus pada kumparan B sementara secara bersamaan mengurangi besarnya arus pada kumparan A, maka akan didapatkan step granularity yang lebih halus antara kumparan A dan kumparan B. Teknik ini disebut microstepping. Gambar 11 berikut menunjukkan profil arus input pada kumparan dengan teknik microstepping ini.

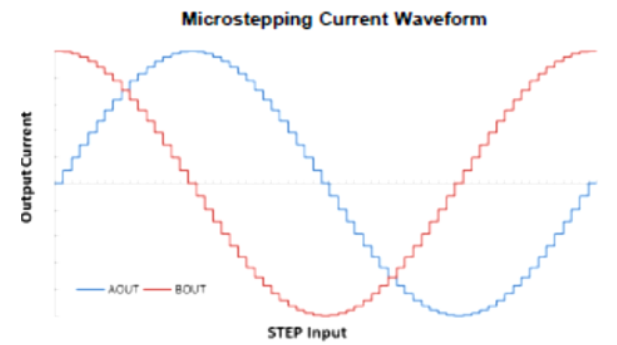

Gambar 11. Profil arus input di kumparan A dan kumparan B untuk microstepping [8] 
Half-stepping dan microstepping menyebabkan motor stepper akan berputar dengan cara yang lebih halus sehingga suara putaran rotor menjadi lebih tidak terdengar. Jumlah step bisa naik secara signifikan, bahkan bisa mencapai 256 kali lipat. Jadi, untuk sebuah motor stepper dengan step angle $\theta$ sebesar $1.8^{\circ}$ akan memberikan 256 x 200 $=51200$ step untuk setiap satu putaran nya. Akan tetapi, presisi untuk microstepping lebih buruk dibandingkan presisi untuk full-stepping.

Kecepatan sebuah motor stepper dapat dinyatakan dalam revolutions per minute (rpm). Tetapi, ketika merujuk pada kecepatan operasionalnya, secara umum satuan kecepatan stepping frequency dinyatakan dalam $\mathrm{Hz}$ atau pps (pulse per second). Selain dipengaruhi oleh switching speed dari motor stepper driver, besarnya stepping frequency $\left(f_{\text {step }}\right)$ yang dibutuhkan juga dipengaruhi oleh karakteristik motor stepper itu sendiri dan beban yang sedang dijalankan. Berkaitan dengan beban yang sedang dijalankan oleh motor stepper, hubungan antara kecepatan dengan torque pada sebuah motor stepper dinyatakan dalam bentuk kurva kecepatantorque.

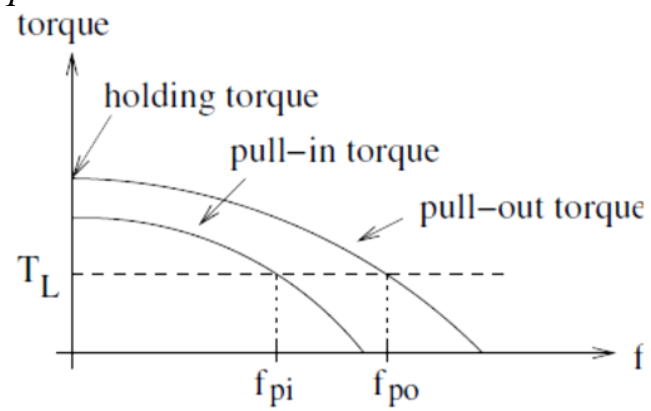

Gambar 12. Kurva kecepatan vs torque dari sebuah motor stepper [2]

Gambar 12 menunjukkan kurva besarnya torque beban maksimum yang tersedia untuk setiap kecepatan. Torque beban harus lebih kecil dibandingkan dengan torque beban maksimum yang diberikan untuk setiap kecepatan tersebut. Demikian pula sebaliknya, apabila nilai torque beban diketahui, maka diagram pada Gambar 12 dapat digunakan untuk menentukan besarnya kecepatan maksimum yang dapat dicapai. Berdasarkan kurva tersebut, besarnya torque beban maksimum yang diperbolehkan akan berkurang seiring dengan bertambahnya kecepatan, sehingga menghasilkan suatu limit stepping frekuensi maksimum yang sesuai untuk sebuah nilai torque pada beban tertentu. Stepping frequency dari berbagai motor stepper biasanya berada dalam rentang $\mathrm{Hz}-\mathrm{kHz}$.

Kurva pada Gambar 12 terdiri atas dua kurva torque. Kurva yang kecil adalah kurva pull-in torque, yang berlaku (valid) hanya pada saat motor stepper dinyalakan. Untuk suatu torque beban tertentu $T_{L}, f_{p i}$ adalah frekuensi maksimum di mana motor bisa dinyalakan tanpa kehilangan step. Jika motor stepper dalam keadaan sedang running, torque akan lebih tinggi. Torque ini diberikan pada kurva pull-out torque. Pada kondisi ini, motor stepper dapat dioperasikan dengan frekuensi $f_{p o}>f_{p i}$. Sebagai konsekuensinya, pada saat terjadi percepatan, motor stepper harus di "ramped". Artinya, pengoperasian motor stepper dimulai dengan suatu stepping rate yang lambat dan kemudian secara berangsur angsur dinaikkan hingga mencapai pull-out rate maksimum [2]. Hal yang sama juga berlaku pada saat motor stepper diperlambat, dimana kecepatan motor diturunkan secara berangsur-angsur sebelum berhenti. Jika hal ini tidak dilakukan, motor stepper bisa kehilangan langkah ketika dinyalakan dan dapat dieksekusi step tambahan ketika motor dihentikan. Sementara torque maksimum pada kecepatan nol disebut dengan holding torque. Apabila torque ini dilampaui, motor stepper tidak dapat menahan beban pada posisi nya.

\subsection{Stepper Motor Control}

Kumparan-kumparan pada suatu motor stepper dapat dikontrol secara langsung (dengan rangkaian driver yang sesuai) yaitu dengan mengatur level arus pada setiap kumparan, seperti dijelaskan pada subbab 2.3 di atas (lihat Gambar 11). Akan tetapi sekarang telah tersedia berbagai driver IC (integrated circuit) yang bisa meringankan tugas mengatur level arus pada motor stepper.

Pada penelitian ini, digunakan IC motor stepper driver dengan jenis DRV8825 yang dirancang oleh Texas Instrument. Driver tipe ini merupakan jenis driver untuk bipolar stepper motor. Beberapa perusahaan motor stepper driver yang lainnya juga menawarkan IC yang serupa, misalnya motor stepper driver A9880.

Ciri umum dari semua IC driver tersebut adalah motor stepper dapat dikontrol hanya dengan menggunakan dua sinyal yang dapat dioperasikan pada IC driver tersebut, yaitu sinyal STEP dan sinyal DIRECTION. Pin DIRECTION akan mengontrol arah perputaran motor stepper searah jarum jam atau berlawanan arah jarum jam. 
Kemudian, apabila suatu gelombang berbentuk pulsa (square waveform) diaplikasikan pada pin STEP, maka motor stepper akan berputar satu langkah dengan arah yang telah ditentukan. Logika kumparan mana yang akan dinyalakan selanjutnya telah diimplementasikan di dalam IC driver tersebut.

Selain kemampuan dasar di atas, beberapa driver juga dilengkapi dengan logika untuk halfstepping dan microstepping. Beberapa IC juga menawarkan suatu free-running mode dengan user-selectable frequencies, dimana motor stepper akan berputar dengan sendirinya segera setelah mode tersebut diaktifkan. Hal ini sangat berguna pada situasi dimana motor stepper hanya diperlukan untuk sekedar berputar tanpa dipengaruhi oleh posisinya.

Untuk mengontrol kecepatan sebuah motor stepper dengan menggunakan sebuah IC motor stepper driver, persyaratan yang dibutuhkan adalah microcontroller yang digunakan harus menghasilkan suatu sinyal step periode dengan frekuensi tertentu. Sebuah keluaran squarewave biasa atau Pulse Width Modulation (PWM) sangat cocok digunakan untuk menghasilkan sebuah sinyal seperti ini.

Driver ICs tersebut pada umumnya mempunyai sebuah nilai step frequency maksimum yang besarnya sama atau lebih besar dari frekuensi stepper motor agar bisa memanfaatkan motor stepper secara maksimal. Seperti telah dijelaskan pada subbab 2.3, jika kecepatan motor harus dinaikkan, laju stepping harus diubah secara berulang-ulang, dimulai dengan pull-in rate dan terus meningkat hingga mencapai pull-out rate. Setiap intermediate rate harus ditahan dalam waktu tertentu sebelum switching ke rate lebih tinggi berikutnya. Hal yang sama juga berlaku untuk perlambatan, tetapi biasanya motor dapat diperlambat secara lebih cepat dibandingkan pada saat dipercepat.

Beberapa high-end microcontroller telah dilengkapi dengan fitur ramping yang diberikan dalam bentuk ramp tables, namun pada microcontrollers sederhana, profil ramping tersebut harus dirancang terlebih dahulu.

\subsection{DRV8825 Stepper Motor Control IC}

Motor kontroler IC DRV8825 yang digunakan pada penelitian ini menyediakan suatu solusi integrated motor driver yang dapat digunakan pada printer, scanner dan aplikasi peralatan otomasi lainnya. Perangkat ini mempunyai dua $H$ - bridge driver dan satu microstepping indexer yang diperuntukkan untuk menjalankan suatu stepper motor bipolar. Blok output driver terdiri dari beberapa N-channel power MOSFET yang dikonfigurasikan sebagai full $\mathrm{H}$-bridges sebagai drive kumparan motor stepper. Driver ini mempunyai kemampuan untuk menggerakkan arus hingga sebesar 2.5 Ampere dari tiap-tiap output motor tersebut (dengan heat sinking yang tepat pada 24 Volt dan $25^{\circ} \mathrm{C}$ ).

DRV8825 dapat diberi daya dengan suatu tegangan supply antara $8.2 \mathrm{~V}$ sampai $45 \mathrm{~V}$ dan mampu menyediakan keluaran arus hingga $2.5 \mathrm{~A}$ pada skala penuh. Sementara, fitur STEP/DIR sederhana memungkinkan kemudahan antarmuka ke rangkaian controller (pada penelitian ini adalah rangkaian mikrokontroller). Fasilitas internal indexer pada driver ini mempunyai kemampuan untuk mengeksekusi high-accuracy microstepping tanpa mengharuskan mikrokontroler mengontrol level arus.

Pada driver ini terdapat tiga pin $M O D E$ yang dapat digunakan untuk mengkonfigurasi rangkaian pengontrol ini. Pin-pin MODE tersebut dapat digunakan untuk konfigurasi motor stepper mulai dari mode full-step sampai mode $32 \frac{\mu \text { steps }}{\text { step }}$.

\section{Metode Penelitian}

Penelitian ini dilakukan dengan merancang suatu sistem rangkaian seperti terlihat pada blok diagram pada Gambar 13 berikut ini:

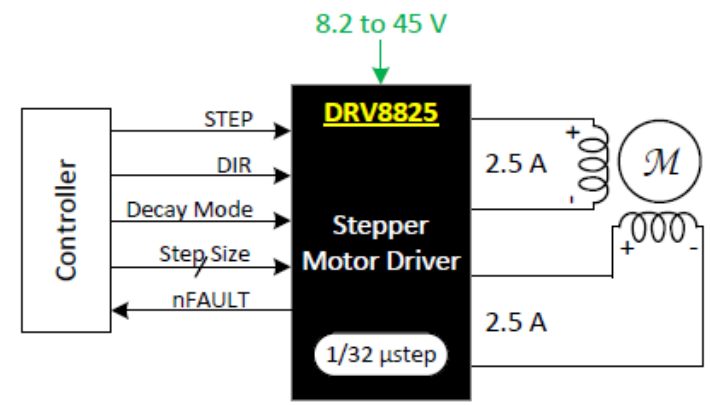

Gambar 13. Sistem Rangkaian yang dibuat [8]

Pada Gambar 13 terlihat bahwa sistem ini terdiri atas tiga bagian utama. Bagian pertama adalah rangkaian kontroler, pada penelitian ini berupa mikrokontroller yang berfungsi sebagai penyedia gelombang square wave (pembangkitan gelombang squarewave menggunakan fitur Timer 
MCU). Bagian kedua adalah rangkaian motor stepper driver, yaitu DRV8825. Pada bagian ini berbagai pin yang terdapat pada IC tersebut dihubungkan ke rangkaian pengontrol, motor stepper, dan suplai tegangan. Bagian ketiga sistem ini adalah motor stepper. Ada empat kabel pada motor stepper yang digunakan. Keempat kabel tersebut merupakan kabel dari kumparan didalam motor. Jadi, dapat diketahui bahwa semua koneksi pada rangkaian ini menggunakan kabel. Sebagai suatu perbandingan, terdapat penelitian yang dilakukan oleh Ifrah Jaffri1, Zeeshan Nafees, Shoaib Zaidi, Oliver Faust yang merancang suatu wireless stepper motor control system [3].

\subsection{Pembangkitan Waveform}

Langkah pertama dalam konfigurasi DRV8825 memerlukan data tentang kecepatan motor yang diinginkan dan level microstepping yang akan digunakan. Apabila aplikasi target (aplikasi yang dikendalikan oleh motor stepper) membutuhkan suatu kecepatan konstan, maka suatu square wave dengan frekuensi sebesar $f_{\text {step }}$ harus diaplikasikan ke pin STEP pada DRV8825.

Pembangkitan waveform square wave tersebut dapat dilakukan dengan dua cara. Pertama, dengan menghubungkan pin STEP pada DRV8825 dengan salah satu pin I/O pada GPIO dari MCU. Kemudian pin tersebut diatur dengan kondisi $H I G H$ dan $L O W$ dengan periode $H I G H$ dan $L O W$ yang dapat diatur pada bagian programnya. Cara ini sebenarnya hanya memanfaatkan fitur hardware I/O yang terdapat pada MCU tersebut. Cara lain adalah menggunakan pembangkitan waveform melalui fitur Timer yang tersedia pada microcontroller AVR. Timer 0 yang terdapat pada Mikrokontroler AVR ini dapat dioperasikan dengan beberapa mode, salah satunya adalah mode Clear Timer on Compare Match (CTC).

Untuk bisa menghasilkan suatu waveform keluaran (berupa squarewave waveform) pada mode CTC ini, keluaran OCOA (PD6) bisa disetel untuk men-toggle level logika pada setiap compare match dengan cara mengatur Compare Output mode bit pada mode toggle (COM0A1:0= 1). Nilai $O C O A$ tidak akan terlihat pada port pin (pada PD6) sebelum data direction untuk pin tersebut diatur ke mode output. Waveform yang dihasilkan akan mempunyai frekuensi maksimum sebesar $f_{O C O}=f_{\text {clk_IO }} / 2$ pada saat $O C R O A$ di set ke nol (0x00). Frekuensi waveform didefinisikan oleh persamaan (1) berikut ini :

$$
f_{\text {OCn } x}=\frac{f_{\text {clk_IO }}}{2 . N .(1+O C R n x)}
$$

Dimana variabel $\mathrm{N}$ merepresentasikan faktor prescale $(1,8,64,256$, atau 1024) [1].

\subsection{Perhitungan Besarnya Frekuensi Waveform}

Apabila kecepatan startup dari motor stepper terlalu tinggi, motor stepper tidak akan berputar. Maka harus dipastikan bahwa motor stepper dapat menunjang kecepatan yang ditargetkan. Metode lainnya adalah dengan mengimplementasikan suatu profil pemrograman percepatan yang akan menggerakkan motor stepper hingga kecepatan yang ditargetkan tersebut.

Untuk suatu kecepatan motor stepper yang diinginkan sebesar (v), level microstepping yang dipilih sebesar $\left(n_{m}\right)$, dan step angle tertera dari motor stepper sebesar $\left(\theta_{\text {step }}\right)$, maka diperoleh [8]:

$$
f_{\text {step }}(\mu \text { steps } / \text { second })=
$$

$$
\frac{v\left(\frac{\text { rotations }}{\text { minute }}\right) \times 360\left(\frac{\circ}{\text { rotation }}\right) \times n_{m}\left(\frac{\mu \text { steps }}{\text { step }}\right)}{60\left(\frac{\text { seconds }}{\text { minute }}\right) \times \theta_{\text {step }}\left(\frac{\circ}{\text { step }}\right)}
$$

Persamaan (2) diperoleh sebagai berikut: motor stepper yang digunakan pada penelitian ini mempunyai step angle sebesar $1.8^{\circ}$. Untuk melakukan satu putaran penuh $\left(360^{\circ}\right)$ maka diperlukan sejumlah $\frac{360^{\circ}}{1.8^{\circ}}=200$ step. Perhitungan jumlah $\mu$ steps secara keseluruhan untuk satu kali rotasi didapat dengan mengkalikan 200 step di atas dengan level $\frac{\mu \text { steps }}{\text { step }}$ yang dipilih. Jadi, untuk satu kali putaran penuh, jumlah $\mu$ steps tergantung pada level $\frac{\mu \text { steps }}{\text { step }}$ yang dipilih.

Untuk melakukan rotasi dengan kecepatan $\mathrm{v}$ $\frac{\text { rotasi }}{\text { menit }}$, maka jumlah $\mu$ steps yang diperlukan adalah jumlah $\mu$ steps untuk satu kali rotasi dikalikan dengan jumlah $\frac{\text { rotasi }}{\text { menit }}$ yang diinginkan. Jika diubah dalam satuan rotasi per detiknya, maka nilai tersebut dibagi dengan $60 \frac{\text { detik }}{\text { menit }}$.

Level microstepping pada IC driver DRV8825 bisa diatur dengan tiga pin $M O D E$ dengan konfigurasi yang tertera pada Tabel 1 . Microstepping yang lebih tinggi atau level $\frac{\mu \text { steps }}{\text { step }}$ yang lebih tinggi berarti akan menghasilkan pergerakan motor yang lebih halus sehingga suara motor stepper menjadi lebih tidak terdengar. Akan tetapi, hal ini akan menaikkan switching losses 
dan membutuhkan suatu input $f_{\text {step }}$ yang lebih tinggi untuk mendapatkan kecepatan motor stepper yang sama (lihat rumus).

Tabel 1. Tiga Mode pin untuk memilih level Microstepping

\begin{tabular}{|c|c|c|c|}
\hline MODE2 & MODE1 & MODE0 & STEP MODE \\
\hline $\mathbf{0}$ & $\mathbf{0}$ & $\mathbf{0}$ & $\begin{array}{c}\text { Full step (2-phase } \\
\text { excitation) with } 71 \% \\
\text { current }\end{array}$ \\
$\mathbf{0}$ & $\mathbf{0}$ & $\mathbf{1}$ & $1 / 2$ step (1-2 phase \\
& & & excitation) \\
$\mathbf{0}$ & $\mathbf{1}$ & $\mathbf{0}$ & $1 / 4$ step (W1-2 phase \\
& & & excitation) \\
$\mathbf{0}$ & $\mathbf{1}$ & $\mathbf{1}$ & 8 microsteps/step \\
$\mathbf{1}$ & $\mathbf{0}$ & $\mathbf{0}$ & 16 microsteps/step \\
$\mathbf{1}$ & $\mathbf{0}$ & $\mathbf{1}$ & 32 microsteps/step \\
$\mathbf{1}$ & $\mathbf{1}$ & $\mathbf{0}$ & 32 microsteps/step \\
$\mathbf{1}$ & $\mathbf{1}$ & $\mathbf{1}$ & 32 microsteps/step \\
\hline
\end{tabular}

\subsection{Percobaan Mode Stepping}

Built-in indexer logic yang terdapat pada DRV8825 memungkinkan serangkaian konfigurasi stepping yang berbeda-beda yang dapat dilakukan. Pada driver tersebut terdapat tiga pin $M O D E$ yaitu MODEO hingga MODE2 yang bisa digunakan untuk konfigurasi format stepping seperti yang ditunjukkan pada Tabel 1.

Langkah pertama yang dilakukan adalah dengan mencoba mode full-stepping dengan cara mengatur $M O D E O$ ke $L O W, M O D E 1$ ke $L O W$, dan $M O D E 2$ ke $L O W$. Demikian juga seterusnya untuk berbagai stepping lainnya dimana nilai-nilai $M O D E 1, M O D E 2$ dan MODE3 disesuaikan.

\section{Hasil Penelitian}

Beberapa jenis percobaan dilakukan pada penelitian ini. Tabel 1 menunjukkan hasil percobaan ketika digunakan level microstepping yang lebih tinggi, sehingga menghasilkan suara motor stepper menjadi lebih tidak terdengar dan menjadi lebih halus.

Tabel 2. Hasil percobaan berbagai level stepping

\begin{tabular}{|c|c|c|c|c|}
\hline Step & $\underset{(\mathrm{KHz})}{\boldsymbol{f}_{\text {clock-IO }}}$ & OCROA & $\begin{array}{c}\boldsymbol{f}_{\text {stepping }} \\
(\mathrm{Hz})\end{array}$ & $\begin{array}{l}\text { Suara } \\
\text { Motor }\end{array}$ \\
\hline Full & 250 & $0 \times 66$ & 1213,59 & $\mathrm{~S}$ \\
\hline Half & 250 & $0 \times 33$ & 2403,85 & M \\
\hline $1 / 4$ & 2000,00 & $0 \times B B$ & 5319,15 & $\begin{array}{l}\mathrm{O} \\
\mathrm{O}\end{array}$ \\
\hline $8 \mu$ & 2000,00 & $0 \times 66$ & 9708,74 & $\mathrm{~T}$ \\
\hline $16 \mu$ & 2000,00 & $0 \times 33$ & $19.230,00$ & $\mathrm{H}$ \\
\hline $32 \mu$ & $16.000,00$ & $0 x C C$ & $37.558,69$ & $\begin{array}{l}E \\
R\end{array}$ \\
\hline
\end{tabular}

Pada penelitian ini juga dilakukan percobaan untuk menggerakkan perputaran motor stepper dengan dua arah yaitu arah clockwise dan arah anti-clockwise. Ini dilakukan dengan mengubah nilai pada port pin di mikrokontroler yang dihubungkan dengan pin DIR pada motor stepper driver. Nilai port tersebut diubah dari nilai $H I G H$ ke $L O W$ atau sebaliknya. Pada percobaan ini, diperoleh hasil bahwa ketika nilai port pin pada mikrokontroler $H I G H$, motor stepper berputar ke satu arah. Sebaliknya, ketika nilai port pin $L O W$, maka motor stepper berputar ke arah yang sebaliknya.

Percobaan selanjutnya adalah mengerakkan motor stepper dengan interval waktu tertentu. Kondisi motor $O N$ untuk suatu interval waktu tertentu dan kemudian $O F F$ untuk suatu interval waktu tertentu lainnya. Percobaan ini dilakukan untuk mengantisipasi tipe pergerakan motor stepper yang tidak kontinu. Pada beberapa perangkat yang menggunakan motor stepper, bisa diamati bahwa tipe perputaran motor stepper kadang tidak secara kontinu, yaitu terdapat jeda diam diantara dua perputaran berurutan pada motor stepper tersebut. Motor stepper ini dihentikan dengan cara men-disconnect-kan OC0A output pada Timer 0 mikrokontroler.

Percobaan selanjutnya dilakukan untuk menganalisa percepatan dan perlambatan pada motor stepper. Level microstepping yang digunakan adalah $16 \frac{\mu \text { steps }}{\text { step }}$ dan $f_{\text {clk_lo }}$ sebesar 2 MHz. Hasil percobaan ini ditunjukkan pada Tabel 3.

Percobaan ini dimulai dengan memberikan nilai OCR0A dengan nilai frekuensi maksimum yang memungkinkan tanpa menyebabkan motor stepper kehilangan step. Kemudian dilanjutkan dengan menaikkan $f_{\text {step }}$ secara berangsur angsur (dilakukan dengan mengurangi nilai OCROA). Hal ini menyebabkan motor stepper dipercepat secara berangsur-angsur. Apabila dimulai dengan frekuensi step yang tinggi, misalnya memilih secara langsung frekuensi step $27027.03 \mathrm{~Hz}$, motor stepper tidak akan berputar. Hal yang sama berlaku pada saat motor stepper diperlambat dengan cara pemberian nilai OCR0A yang tinggi secara tidak langsung. 
Tabel 3. Hasil percepatan dan perlambatan motor

\begin{tabular}{|c|c|c|c|}
\hline$\frac{\mu \text { steps }}{\text { step }}$ & OCR0A & $\begin{array}{l}\text { Frekuensi } \\
\boldsymbol{f}_{\boldsymbol{s t e p}}(\mathrm{Hz})\end{array}$ & Hasil \\
\hline $\begin{array}{l}16 \\
16 \\
16 \\
16 \\
16 \\
16 \\
16 \\
16 \\
16 \\
16 \\
16 \\
16 \\
\end{array}$ & $\begin{array}{l}\text { 0x35 } \\
0 \times 34 \\
0 \times 33 \\
0 \times 32 \\
0 \times 31 \\
0 \times 30 \\
0 \times 29 \\
\text { 0x28 } \\
\text { 0x27 } \\
\text { 0x26 } \\
\text { 0x25 } \\
\text { 0x24 }\end{array}$ & $\begin{array}{l}18518.52 \\
18867.92 \\
19230.77 \\
19607.84 \\
20000.00 \\
20408.16 \\
23809.52 \\
24390.24 \\
25000.00 \\
25641.03 \\
26315.79 \\
27027.03 \\
\end{array}$ & $\begin{array}{l}\mathrm{P} \\
\mathrm{E} \\
\mathrm{R} \\
\mathrm{C} \\
\mathrm{E} \\
\mathrm{P} \\
\mathrm{A} \\
\mathrm{T} \\
\mathrm{A} \\
\mathrm{N}\end{array}$ \\
\hline $\begin{array}{l}16 \\
16 \\
16 \\
16 \\
16 \\
16 \\
16 \\
16 \\
16 \\
16 \\
16\end{array}$ & $\begin{array}{l}\text { 0x25 } \\
0 \times 26 \\
0 \times 27 \\
0 \times 28 \\
0 \times 29 \\
0 \times 30 \\
0 \times 31 \\
0 \times 32 \\
0 \times 33 \\
0 \times 34 \\
0 \times 35\end{array}$ & $\begin{array}{l}26315.79 \\
25641.03 \\
25000.00 \\
24390.24 \\
23809.52 \\
20408.16 \\
20000.00 \\
19607.84 \\
19230.77 \\
18867.92 \\
18518.52\end{array}$ & $\begin{array}{l}\text { P } \\
\text { E } \\
\text { R } \\
\text { L } \\
\text { A } \\
\text { M } \\
\text { B } \\
\text { A } \\
\text { T } \\
\text { A } \\
\text { N }\end{array}$ \\
\hline
\end{tabular}

Percobaan tambahan yang juga merupakan percobaan terakhir pada penelitian ini adalah aplikasi rangkaian ini dengan menggunakan motor stepper tipe hybrid. Percobaan ini menunjukkan hasil yang sama seperti hasil yang dilakukan pada motor stepper tipe permanent magnet.

\section{Kesimpulan}

Dari hasil penelitian ini dapat disimpulkan beberapa hal sebagai berikut:

a. Perbaikan resolusi rotor dapat dilakukan dengan metode software yaitu dengan menggunakan berbagai mode stepping.

b. Motor stepper driver menyediakan fasilitas internal indexer yang mempunyai kemampuan untuk mengeksekusi high accuracy microstepping tanpa mengharuskan mikrokontroler untuk mengontrol level arus.

c. Timer pada mikrokontroler dapat digunakan untuk menghasilkan suatu square wave yang akan menjadi input pada pin STEP dari motor stepper driver.

d. Pada percobaan dengan menggunakan masukan berbagai pola stepping, terbukti bahwa dengan menggunakan level microstepping yang lebih tinggi menyebabkan suara motor stepper menjadi lebih tidak terdengar.

e. Pada percepatan dan perlambatan, bisa dilihat bahwa dengan merancang suatu program dengan profil percepatan dan perlambatan, maka pergerakan motor stepper tidak akan mengalami kemacetan.

f. Berbagai pergerakan rotasional yang bermanfaat bisa dilakukan dengan cara mengatur program (software) yang berisi pembangkitan gelombang square wave.

g. Rangkaian pengontrol ini juga dapat digunakan untuk tipe motor stepper hybrid.

\section{Daftar Pustaka}

[1] Atmel, "Atmel 8-Bit Microcontroller With 4/8/16/32kbytes In-System Programmable Flash Datasheet", Atmel Corporation, 2014

[2] Günther Gridling, Bettina Weiss, "Introduction to Microcontrollers", Vienna University of Technology Institute of Computer Engineering Embedded Computing Systems Group, 2007

[3] Ifrah Jaffri1, Zeeshan Nafees, Shoaib Zaidi, Oliver Faust, "BlueSteps: A Bluetooth Based Stepper Motor Control System", School of Science and Engineering, Habib University, Karachi, Pakistan Electrical, Electronic Control Engineering, Sheffield Hallam University, Sheffield, England, UK

Journal of Embedded Systems, , Vol. 3, No. 1, 21-27,2015

[4] Ivan Virgala, Michal Kelemen, Alexander Gmiterko, Tomáš Lipták, " Control of Stepper Motor by Microcontroller", Department of Mechatronics, Technical University of Košice, Faculty of Mechanical Engineering, Košice, Slovakia, Journal of Automation and Control, 2015, Vol. 3, No. 3, 131-134

[5] Marc McComb, "Introduction to Stepper Motors Part 1 : Types of Stepper Motors", Microchip, 2007

[6] Marc McComb, "Introduction to Stepper Motors Part 2 : Stepper Motor Control", Microchip, 2007

[7] Schneider Electric, "NEMA size $231.8^{\circ}$ 2-phase bipolar stepper motor Data Sheet", Schneider Electric Motion USA, 
[8] Texas Instrument, "DRV8825 Stepper Motor Controller", 2014

\section{Biodata Penulis}

Arief Wisnu Wardhana, Menyelesaikan pendidikan S1 Engineering dalam bidang Electronic \& Information dari University of Huddersfield, Huddersfield, The United Kingdom pada tahun 1997. Kemudian menyelesaikan Pasca Sarjana S2 Konsentrasi Sistem Isyarat Elektronik di Jurusan Teknik Elektro Fakultas Teknik Universitas Gadjah Mada Yogyakarta pada tahun 2016. Saat ini, penulis adalah dosen Jurusan Teknik Elektro, Fakultas Teknik Universitas
Jenderal Soedirman, Purwokerto, Indonesia, bidang keahlian Sistem Isyarat dan Kendali. Interest utama pada area embedded system dan embedded programming.

Daru Tri Nugroho, Menyelesaikan pendidikan S1 Teknik dalam bidang Teknik Elektro dari Institut Teknologi Sepuluh November Surabaya, Indonesia pada tahun 2001. Kemudian menyelesaikan S2 Teknik dalam bidang Teknik Elektro dari Universitas Indonesia, Indonesia pada tahun 2006. Saat ini penulis adalah dosen Jurusan Teknik Elektro, Fakultas Teknik Universitas Jenderal Soedirman, Purwokerto, Indonesia, bidang sistem tenaga. 